\title{
TOXIC IMPACT OF SOME INSECT GROWTH REGULATORS AND BIOCIDES IN RELATIVE TO CHLORPYRIFOS TO COTTON LEAFWORM, SPODOPTERA LITTORALIS (BOISD.)
}

\author{
EL-KHAYAT, E. F. ${ }^{1}$, W. M. H. DESUKY ${ }^{2}$, M. M. AZAB ${ }^{1}$ AND M. M.A. KHEDR ${ }^{2}$ \\ 1. Plant Protection Department, Faculty of Agric. Benha Univ., Egypt \\ 2. Plant Protection Research Institute, ARC, Dokki, Giza, Egypt.
}

(Manuscript received 21 June 2011)

\begin{abstract}
The stomach poisonous impact of some insect growth regulators and biocides was tested under laboratory and semi-field conditions against cotton leafworm, $S$. littoralis. Obtained results revealed that, the second instar larvae reflected higher level of susceptibility towards all the tested insecticides than fourth one. According to $\mathrm{LC}_{50}$ and $\mathrm{LC}_{90}$ values, chlorpyrifos was the most effective insecticide that recorded 0.1 and $0.809 \mathrm{ppm}$ for $2^{\text {nd }}$ instar larvae and 0.472 and $6.838 \mathrm{ppm}$ for $4^{\text {th }}$ instar larvae, respectively. Meanwhile, tebufenozide appeared to be the least effective compound against both tested instars that gave 9.901and 36.447 ppm against $2^{\text {nd }}$ instar, whereas the $\mathrm{LC}_{50}$ and $\mathrm{LC}_{90}$ values were 65.736 and $1000.775 \mathrm{ppm}$ ) against the $4^{\text {th }}$ one, respectively. The rest compounds gave moderate effects in this respect.

Data concerning the initial and residual activity of the tested insecticides, Tracer, $X D E$, methoxyfenozide, Dipel $2 x$ and chlorpyrifos against $4^{\text {th }}$ instar larvae of field strain cotton leafworm, $S$. littoralis were determined. The initial effect calculated as the cumulative mortalities at zero time recorded 100,100, 92, 88 and $26 \%$ for methoxyfenozide, chlorpyrifos, XDE, Tracer and Dipel $2 x$, respectively. The untreated check recorded $2 \%$, methoxyfenozide and chlorpyrifos gave the highest significant mortalities effects comparing to the untreated, Chlorpyrifos and methoxyfenozide were detected the highest significant mortalities effect as general residual effect whereas Dipel $2 x$ recorded the least significant mortality effect, which it being $18.40 \%$ as compared to other insecticides.
\end{abstract}

\section{INTRODUCTION}

The cotton leafworm, Spodoptera littoralis (Boisduval) (Lepidoptera: Noctuidae) is one of the key pests that cause great damage to cotton plants as well as other plants in Egypt Willcocks and Bahgat, (1937), larvae of this pest can feed on $\approx 90$ economically important plant species belonging to 40 families. To combat the pest, growers use synthetic organic insecticides and some biorational agents such as Bacillus thuringiensis Berliner, but the achieved control is not successful because of the insect's high capacity to develop resistance toward the majority of conventional 
compounds. Therefore, scientists and growers are seeking alternative materials that are effective against this pest, safe to humans, environmental friendly, and compatible within targeted pest management (IPM) practices. The alternative control tactics that show promise as a potential tool in $S$. littoralis resistant management programs is the use of biorational control agents such as synthetic insect growth regulators (IGRs) and those based on naturally derived products. IGRs are claimed to be safer for beneficial organisms than conventional products, and they have been successfully used in IPM programs against many tree and small fruit pests.

There is a need for different insecticides having different modes of action. Spinosad is a naturally derived biorational insecticide with an environmentally favorable toxicity profile. It is an insecticide based on an aerobic fermentation product of the bacterium Saccharopolyspora spinosa on nutrient media, Spinosad is a mixture of spinosyns A and D. In many countries, spinosad is used for controlling lepidopteran pests in cotton, tobacco and other crops. It has a novel mode of action, acting primarily at the nicotinic acetylcholine receptor in the nerve synapses. Continuous activation of motor neurones causes spasmatic paralyses of muscles and the insect dies from exhaustion Pineda et. al., (2006).

The goal of this study was to evaluate the toxicity of Teflubenzuron, Tebufenozide, Methoxyfenozide, Spinosad, Dipel $2 x$ and chlorpyrifos against the cotton leafworm, $S$. littoralis instar larvae under laboratory and semi-field conditions.

\section{MATERIALS AND METHODS}

\section{Tested compounds:}

\subsection{Insect growth regulators:}

A. Trade name: Nomolt ${ }^{\circledR} 15 \%$ Suspension Concentrate (SC).

Common name: Teflubenzuron.

Chemical name: $\quad N$-[[(3,5-dichloro-2,4-difluorophenyl)amino]carbonyl]-2,6difluorobenzamide)

Rate: $50 \mathrm{~cm}^{3} / 100 \mathrm{~L}$.

Basic product: BASF Co.

B: Trade name: Mimic ${ }^{\circledR} 24 \%$ Emulsifiable Concentrate (EC).

Common name: Tebufenozide.

Chemical name: 3,5-dimethylbenzoic acid 1-(1,1-dimethylethyl)-2-(4-ethylbenzoyl) hydrazide.

Rate: $350 \mathrm{~cm}^{3}$ /feddan.

Basic product: Dow AgroSciences. 
C: Trade name: Runner ${ }^{\circledR}$ 24\% Suspension Concentrate (SC).

Common name: Methoxyfenozide.

Chemical name: 3-methoxy-2-methylbenzoic acid 2-(3,5-dimethylbenzoyl)-2-(1,1dimethylethyl) hydrazide.

Rate: $150 \mathrm{~cm}^{3}$ / feddan.

Basic product: Dow AgroSciences Co.

\subsection{Bio-insecticides:}

A. Trade name: Tracer $^{\circledR}$

Common name: Spinosad 24\% Suspension Concentrate (SC). Tracer is comprised primarily of two macrocyclic lactones, Spinosyn A and D, secondary metabolites produced by the actinomycete, Saccharopolyspra spinosa under natural fermentation condition.

Rate: $50 \mathrm{~cm}^{3}$ / feddan.

Basic product: Dow AgroSciences Co.

B: Trade name: $X E^{\circledR}$

Common name: Tracer

Rate: $104 \mathrm{~cm}^{3}$ /feddan.

Basic product: Dow AgroSciences Co.

C: Trade name: Dipel $2 x^{\circledR}$ (6.4 \% WP).

Common name: Bacillus thuringiensis subsp. Kurstaki 32, 000 International Units of potency per $\mathrm{mg}$.

Rate: 500 gram / feddan

Basic product: Chemical and Agricultural Products Division, Abbott Laboratories USA.

\subsection{Organophosphorus:}

- Trade name: Chlorpyrifos ${ }^{\circledR}$ (48\% EC).

Common name: Dursban.

Chemical name: 0, 0 - diethyl 0- (3, 5, 6-trichloro-2-pyridinyl) phosphorothioate.

Rate: 1 liter / feddan.

Basic product: Dow AgroSciences.

\section{Rearing technique of cotton leafworm, Spodoptera littoralis (Boisd.):}

A laboratory strain of $S$. littoralis was reared in the laboratory away from any insecticidal contamination at the department of Cotton Leafworm, Branch of Plant Protection Research Institute at Zagazig, Sharqia Governorate under constant conditions $27 \pm 1{ }^{\circ} \mathrm{C}$ and $70 \pm 5 \%$ R.H. to provide insects used in the present investigation. Egg-masses were placed on leaves of castor bean oil, Ricinus communis in cylindrical glass jars (1 lb.) El-Defrawi et. al. (1964). 


\section{Toxic effects of tested insecticides against cotton leafworm, Spodoptera littoralis (Boisd.) under laboratory conditions:}

The efficiency of the different insecticides, teflubenzuron, tebufenozide, methoxyfenozide, Tracer, Dipel $2 x$ and chlorpyrifos, were assessed against the $2^{\text {nd }}$ and $4^{\text {th }}$ instar larvae. Serial successive concentrations of each insecticide starting with the recommended concentration were prepared using distilled water.

Disks $(9 \mathrm{~cm}$. diameter) of castor bean leaves were dipped in the tested concentrations for 10 seconds then left to dry and offered to larvae, which starved for 4-6 hours before treatment (Merdan, 1968). Larvae were placed into glass jars (5 pounds), each treatment was replicated 5 times (10 larvae per each). Control disks were dipped in distilled water only. The larvae were allowed to feed on treated disks for $48 \mathrm{hr}$. then transferred to the untreated ones.

Mortality percentages were recorded after $72 \mathrm{hr}$. for all insecticides except chlorpyrifos after $24 \mathrm{hr}$. Mortality was corrected according to Abbott's formula (1925). The dosages mortality regression lines were statistically analyzed by probit analysis (Finney, 1971). Toxicity Index and Relative Potency calculated according to Sun equations, (1950):

Toxicity index $=\frac{\mathrm{LC}_{50} \text { or } \mathrm{LC}_{90} \text { of the most efficient compound }}{\mathrm{LC}_{50} \text { or } \mathrm{LC}_{90} \text { of the other compound }} \times 100$

\section{Field-laboratory evaluation of the tested insecticides against the $4^{\text {th }}$ instar larvae of $\boldsymbol{S}$. littoralis (Boisd.):}

The purpose of this study was to evaluate the initial and residual effects of the tested selected agents, Tracer, XDE, methoxyfenozide, Dipel $2 \mathrm{x}$ and chlorpyrifos, at the recommended concentrations against field strain $4^{\text {th }}$ instar larvae of the cotton leafworm, S. littoralis.

Samples of cotton leaves were picked up at random for each treatment at zero time directly after spraying, 1, 3, 5, 7 and 9 days post treatment. The collected samples were sealed in paper bags and transferred to the laboratory where they were offered to cotton leafworm larvae (Aly, 1999).

Ten larvae were placed in each glass jar and allowed to feed on the treated leaves for 2 days then survived larvae were transferred to other clean jars and supplied with fresh clean castor bean leaves for 3 days. Five replicates were used for each treatment. Cumulative mortalities were calculated at the end of each testing time and corrected according to Abbott's formula (1925). 
The mortalities at the zero time were considered as initial kill, while the mean of the cumulative mortalities of the remaining tested times were considered as residual effect.

\section{Statistical analysis:}

The significance of the main effects was determined by analysis of variance (ANOVA). The significance of various treatments was evaluated by Duncan's multiple range test $(p<0.05)$ (Snedecor \& Cochran 1980). Data were subjected to statistical analyses using a software package CoStat ${ }^{\circledR}$ Statistical Software (2005) a product of Cohort Software, Monterey, California.

\section{RESULTS AND DISCUSSION}

\section{Toxic effects of some insecticides against the cotton leafworm, Spodoptera littoralis (Boisd.):}

Six insecticides belonging to different groups were selected to study their toxic effects against the $2^{\text {nd }}$ and $4^{\text {th }}$ instar larvae of $S$. littoralis as follows: organophosphorus (chlorpyrifos), insect growth regulators (teflubenzuron, tebufenozide and methoxyfenozide) and bio-insecticides (Tracer and Dipel $2 x$ ). The toxic effects were listed after 72 hours for all treatments with the exception of chlorpyrifos which recorded after 24 hours due to heir mode of action.

\subsection{Susceptibility of different instar larvae of $S$. littoralis to certain insecticides:}

Data presented in Tables (1 and 2) summarized the efficacy of different tested insecticides against $2^{\text {nd }}$ and $4^{\text {th }}$ instar larvae except Dipel $2 x$ which its higher concentration applied gave mortality percentages did not exceed about 30\% until 5 days post treatment, The second larval instar showed higher level of susceptibility towards the tested insecticides than the fourth one.

\subsection{Toxicity of some insecticides against $S$. littoralis:}

According to $\mathrm{LC}_{50}$ and $\mathrm{LC}_{90}$ values, chlorpyrifos was the most effective insecticide where the $\mathrm{LC}_{50}$ and $\mathrm{LC}_{90}$ values recorded $0.1,0.809 \mathrm{ppm}$ for $2^{\text {nd }}$ instar and 0.472 and $6.838 \mathrm{ppm}$ for the $4^{\text {th }}$ instars larvae, respectively. Meanwhile, tebufenozide appeared to be the least effective against both tested instars, where the $\mathrm{LC}_{50}$ and $\mathrm{LC}_{90}$ values against $2^{\text {nd }}$ instar were 9.901 and $36.447 \mathrm{ppm}$ and the values against the $4^{\text {th }}$ one were 65.736 and 1000.775 ppm, respectively. The rest compounds gave moderate effects against both instars that manifested, the $\mathrm{LC}_{50}$ and $\mathrm{LC}_{90}$ levels were 0.204 and $2.311 \mathrm{ppm}$ for teflubenzuron, 0.255 and $5.484 \mathrm{ppm}$ for methoxyfenozide 1.001, $12.34 \mathrm{ppm}$ for Tracer and 9.901, $36.447 \mathrm{ppm}$ for tebufenozide, respectively for 
$2^{\text {nd }}$ instar larvae. As for $4^{\text {th }}$ instar larvae $\mathrm{LC}_{50}$ and $\mathrm{LC}_{90}$ for methoxyfenozide, teflubenzuron and Tracer were (4.27, 153.855 ppm), (8.937, $52.055 \mathrm{ppm})$ and (11.16, 158.019 ppm), respectively, (Tables 1 and 2).

Table 1. Susceptibility of the second instar larvae of Spodoptera littoralis (Boisd.) to different tested insecticides.

\begin{tabular}{|c|c|c|c|c|c|}
\hline Insecticides & $\begin{array}{c}\mathrm{LC}_{50} \text { ppm. } \\
\text { (Lower-Upper) }\end{array}$ & $\begin{array}{c}\text { LC } 90 \text { ppm. } \\
\text { (Lower-Upper) }\end{array}$ & Slope & $\begin{array}{c}\text { Toxicity } \\
\text { index }\end{array}$ & $\begin{array}{l}\text { Relative } \\
\text { Potency }\end{array}$ \\
\hline $\begin{array}{c}\text { Nomolt } \\
\text { (Teflubenzuron) }\end{array}$ & $\begin{array}{c}0.204 \\
(0.04-0.293) \\
\end{array}$ & $\begin{array}{c}2.311 \\
(1.464-3.637) \\
\end{array}$ & 1.216 & 49.02 & 2.04 \\
\hline $\begin{array}{c}\text { Mimic } \\
\text { (Tebufenozide) }\end{array}$ & $\begin{array}{c}9.901 \\
(8.747-11.192)\end{array}$ & $\begin{array}{c}36.447 \\
(28.81-50.871) \\
\end{array}$ & 0.962 & 1.01 & 99.01 \\
\hline $\begin{array}{c}\text { Runner } \\
\text { (Methoxyfenozide) }\end{array}$ & $\begin{array}{c}0.255 \\
(0.219-0.445)\end{array}$ & $\begin{array}{c}5.484 \\
(2.107-6.225) \\
\end{array}$ & 2.264 & 39.216 & 2.55 \\
\hline Tracer (Spinosad) & $\begin{array}{c}1.001 \\
(0.748-1.269)\end{array}$ & $\begin{array}{c}12.349 \\
(9.378-17.532)\end{array}$ & 1.174 & 9.99 & 10.01 \\
\hline $\begin{array}{c}\text { Dursban } \\
\text { (Chlorpyrifos) }\end{array}$ & $\begin{array}{c}0.1 \\
(0.038-0.136)\end{array}$ & $\begin{array}{c}0.809 \\
(0.611-2.594) \\
\end{array}$ & 1.409 & 100 & 1 \\
\hline
\end{tabular}

Toxicity Index and Relative Potency based on $\mathrm{LC}_{50}$

Table 2. Susceptibility of the fourth instar larvae of Spodoptera littoralis (Boisd.) to different tested insecticides.

\begin{tabular}{|c|c|c|c|c|c|}
\hline Insecticides & $\begin{array}{c}\text { LC } 50 \text { ppm. } \\
\text { (Lower-Upper) }\end{array}$ & $\begin{array}{c}\text { LC } 90 \text { ppm. } \\
\text { (Lower-Upper) }\end{array}$ & Slope & $\begin{array}{c}\text { Toxicity } \\
\text { index }\end{array}$ & $\begin{array}{l}\text { Relative } \\
\text { Potency }\end{array}$ \\
\hline $\begin{array}{c}\text { Nomolt } \\
\text { (Teflubenzuron) }\end{array}$ & $\begin{array}{c}8.937 \\
(3.036-11.057) \\
\end{array}$ & $\begin{array}{c}52.055 \\
(41.445-143.901)\end{array}$ & 1.675 & 5.281 & 18.934 \\
\hline $\begin{array}{c}\text { Mimic } \\
\text { (Tebufenozide) }\end{array}$ & $\begin{array}{c}65.736 \\
(53.074-82.747) \\
\end{array}$ & $\begin{array}{c}1000.775 \\
(625.948-1890.801)\end{array}$ & 1.084 & 0.718 & 139.271 \\
\hline $\begin{array}{c}\text { Runner } \\
\text { (Methoxyfenozide) }\end{array}$ & $\begin{array}{c}4.27 \\
(1.722-6.964) \\
\end{array}$ & $\begin{array}{c}153.855 \\
(83.707-501.264) \\
\end{array}$ & 0.823 & 11.054 & 9.047 \\
\hline Tracer (Spinosad) & $\begin{array}{c}11.16 \\
(7.819-14.257)\end{array}$ & $\begin{array}{c}158.019 \\
(88.417-481.289)\end{array}$ & 1.113 & 4.229 & 23.644 \\
\hline $\begin{array}{c}\text { Dursban } \\
\text { (Chlorpyrifos) }\end{array}$ & $\begin{array}{c}0.472 \\
(0.345-0.609)\end{array}$ & $\begin{array}{c}6.838 \\
(5.024-10.212)\end{array}$ & 1.104 & 100 & 1 \\
\hline
\end{tabular}

Toxicity Index and Relative Potency based on $\mathrm{LC}_{50}$ 
According to the estimated $\mathrm{LC}_{50}$ values, the second instar larvae reflected higher level of susceptibility towards all the tested insecticides than the fourth one. The obtained conclusion was in harmony with (Mead 2006) when used Consult, chlorpyrifos and tracer against $2^{\text {nd }}$ and $4^{\text {th }}$ instar larvae of $S$. littoralis. Abd El-Latief (2001) came to the same conclusion when tested chlorpyrifos, thiodicarb and chlorfluazuron and he found that the mortality percentages among older larvae were obviously less than among younger ones especially at the lower concentrations of five bacterial formulations and $2^{\text {nd }}$ instar larvae were more susceptible than the $4^{\text {th }}$ one to the three tested compounds, chlorfluazuron, profenofos and fenvalerate.

The higher susceptibility observed in young instars of $S$. littoralis may be contributed to the tolerance levels which were generally less than those of old ones, irrespective of IGRs tested compounds (Bayoumi et. al., 1998) and suggested that the susceptibility of $5^{\text {th }}$ instar larvae of $S$. littoralis was more susceptible than $6^{\text {th }}$ one to abamectin (carbamate) may due in part to greater metabolism of $5^{\text {th }}$ instar than in the $6^{\text {th }}$ one.

On the basis of $\mathrm{LC}_{50}$ and $\mathrm{LC}_{90}$, the present results indicated that, all the tested insecticides have larvicidal activities against both $2^{\text {nd }}$ and $4^{\text {th }}$ instar larvae with the exception of Dipel $2 x$ that caused low toxic effect up to 5 days. Chlorpyrifos have the highest larvicidal and the most toxic insecticide tested against the $2^{\text {nd }}$ and $4^{\text {th }}$ larval instars. The same result was obtained by Abd El-Latief, 2001) when tested various insecticides against eggs and larvae of $S$. littorali. who mentioned that, Dipel $2 x$ and thuringiensin had slight or low insecticidal activities until 5 days against the $2^{\text {nd }}$ and $4^{\text {th }}$ instar larvae of $S$. littoralis.

As for IGRs, the mortality percentages were recorded after 72 hours of treatment, because after 2 days of treatment, the IGR compounds were not effective, the mortality percentages of larvae began after 3 days of treatment. In addition, some IGRs have ovicidal and larvicidal activities against $S$. littoralis (Emam and Degheele, 1993). Pineda et. al. (2006) they found that Spinosad and methoxyfenozide has larvicidal activities against neonates and fourth larval instars of $S$. littoralis under laboratory conditions.

\section{Field-laboratory evaluation of the tested insecticides against $\boldsymbol{S}$. littoralis:}

Data concerning the initial and residual activity of the tested insecticides, Tracer, XDE, methoxyfenozide, Dipel $2 x$ and chlorpyrifos against $4^{\text {th }}$ instar larvae of field strain cotton leafworm, S. littoralis are tabulated in Table (3). 
Table 3. Semi-field evaluation of the tested insecticides against field strain $4^{\text {th }}$ instar larvae of cotton leafworm, S. littoralis.

\begin{tabular}{|c|c|c|c|c|c|c|c|c|c|c|c|c|c|c|}
\hline \multirow{4}{*}{ Treatments } & \multicolumn{14}{|c|}{$\%$ Mortality at the indicated tested times } \\
\hline & \multirow{2}{*}{\multicolumn{2}{|c|}{$\begin{array}{c}\text { Zero time } \\
\text { (initial effect) }\end{array}$}} & \multicolumn{12}{|c|}{ Residual effect } \\
\hline & & & \multicolumn{2}{|c|}{1 day } & \multicolumn{2}{|c|}{3 days } & \multicolumn{2}{|c|}{5 days } & \multicolumn{2}{|c|}{7 days } & \multicolumn{2}{|c|}{9 days } & \multicolumn{2}{|c|}{$\begin{array}{l}\text { General mean of } \\
\text { residual effect }\end{array}$} \\
\hline & $\begin{array}{l}48 \mathrm{hr} . \\
*\end{array}$ & 5 days* & $\begin{array}{c}48 \\
\text { hr. * }\end{array}$ & $\begin{array}{c}5 \\
\text { days* }\end{array}$ & $\begin{array}{c}48 \\
\text { hr. * }\end{array}$ & $\begin{array}{c}5 \\
\text { days* }\end{array}$ & $\begin{array}{c}48 \\
\text { hr. * }\end{array}$ & $\begin{array}{c}5 \\
\text { days* }\end{array}$ & $\begin{array}{c}48 \\
\text { hr. * }\end{array}$ & $\begin{array}{c}5 \\
\text { days* }\end{array}$ & $\begin{array}{c}48 \\
\text { hr. * }\end{array}$ & $\begin{array}{c}5 \\
\text { days* }\end{array}$ & $\begin{array}{c}48 \\
\text { hr. * }\end{array}$ & $\begin{array}{c}5 \\
\text { days* }\end{array}$ \\
\hline Tracer & 84.00 & $88.00 \mathrm{~b}$ & 72.00 & 84.00 & 70.00 & 82.00 & 70.00 & 78.00 & 64.00 & 72.00 & 60.00 & 72.00 & 67.20 & $77.60 \mathrm{~b}$ \\
\hline XDE & 86.00 & $92.00 \mathrm{~b}$ & 82.00 & 90.00 & 76.00 & 84.00 & 70.00 & 84.00 & 64.00 & 80.00 & 62.00 & 74.00 & 70.80 & $82.40 \mathrm{~b}$ \\
\hline Methoxyfenozide & 40.00 & $100.00 \mathrm{a}$ & 50.00 & 100.00 & 36.00 & 96.00 & 42.00 & 96.00 & 30.00 & 92.00 & 28.00 & 90.00 & 37.20 & $94.80 \mathrm{a}$ \\
\hline Dipel 2x & 14.00 & $26.00 \mathrm{c}$ & 12.00 & 22.00 & 14.00 & 20.00 & 10.00 & 20.00 & 8.00 & 18.00 & 8.00 & 12.00 & 10.40 & $18.40 \mathrm{c}$ \\
\hline Chlorpyrifos & 100.0 & $100.00 \mathrm{a}$ & 100.00 & 100.00 & 100.00 & 100.00 & 96.00 & 96.00 & 90.00 & 94.00 & 90.00 & 92.00 & 95.20 & $96.40 \mathrm{a}$ \\
\hline Control & 0 & $2.00 \mathrm{~d}$ & 2.00 & 4.00 & 2.00 & 2.00 & 2.00 & 6.00 & 2.00 & 4.00 & 0.00 & 2.00 & 1.60 & $3.60 \mathrm{~d}$ \\
\hline L.S.D 0.05 & & 5.221 & & & & & & & & & & & & 5.867 \\
\hline
\end{tabular}

*Feeding on treated leaves for 48 hours and then 3 days on untreated leaves.

All the treatments were used at the recommended rates. 
Results indicated the important role of feeding period on treated leaves for 2 days followed by untreated leaves for 3 days. So, the evaluation was assessed using the cumulative mortalities. In this study calculated after 5 days of each test time.

The initial effect that (calculated as the cumulative mortalities at zero time) recorded 100, 100, 92, 88 and $26 \%$ for methoxyfenozide, chlorpyrifos, XDE, Tracer and Dipel 2x, respectively. Control recorded 2\% mortality. Methoxyfenozide and chlorpyrifos gave the highest significant mortalities effects comparing to the control that manifested 96.40 and $98.40 \%$ respectively, (Table, 3 ).

The mean of residual effect that calculated as the mean of cumulative mortalities from day 1 until day 9 after spraying were manifested in Table (3). Chlorpyrifos and methoxyfenozide were detected the highest significant mortalities effect, whereas Dipel $2 x$ recorded the least significant mortality effect $(18.40 \%)$ as compared to other insecticides.

The tested compounds could be arranged descendingly in order to their initial and residual effects as the follows: chlorpyrifos, methoxyfenozide, XDE, Tracer and finally Dipel 2x. Obtained results are in agreement with findings of Al-Shannaf et. al,. (2006) when used conventional insecticides (Avaunt and Lannate) and biocides (Spinosad and Viroset). Generally, all the tested treatments exhibited initial effects more than their residual ones against the $4^{\text {th }}$ instar larvae of field strain of $S$. littoralis at the recommended concentrations. Similar results were obtained by Abd El-Latief (2001) for both $2^{\text {nd }}$ and $4^{\text {th }}$ instars of $S$. littoralis field strain after treating with recommended rates of IGRs. Also, Raslan (2003) when tested recommended doses of spinosad and two IGRs against $3^{\text {rd }}$ instar of field strain larvae recorded similar results.

\section{REFERENCES}

1. Abbott, W. S. 1925. A method of computing the effectiveness of an insecticide. J. Econ. Entomol., 18 (2): 256-267.

2. Abd El-Latief, E. M. 2001. Integrated pest management for cotton in Dakahlia Governorate. Ph. D. Thesis. Fac. Agric., Mansoura Univ., Egypt, 154 p.

3. Al-Shannaf, H. M., W. M. Desuky and S. M. Abd El-Halim. 2006. Effect of some compounds on cotton leafworm, Spodoptera littoralis (Boisd.) and their predators. Egypt. J. Appl. Sci., 21 (4 B): 646-660.

4. Aly, M. M. 1999. Bioactivity of certain plant extracts of Fam. Myrtaceae and other biocides on some pests attacking cotton cultivation. Ph. D. Thesis, Institute of Environmental studies and researches, Ain Shams Univ., 173 p. 
5. Bayoumi, A. E., R. Balana Fouce, A. K. Sobeiha and E. M. Hussein. 1998. The biological activity of some chitin synthesis inhibitors against the cotton leafworm, Spodoptera littoralis (Boisduval), (Lepidoptera: Noctuidae). Boletin de Sanidad Vegetal Plagas, 24 (3): 499-506.

6. El-Defrawi, M. E., A. Toppozada, N. Mansour and M. Zeid. 1964. Toxicological studies on the Egyptian cotton leafworm, Prodenia litura F. susceptibility of different larval instars of Prodenia to insecticides. J. Econ. Entomol., 57: 591-593.

7. Emam, A. K. and D. Degheele. 1993. Delayed effect of some benzoylphenyl ureas applied to fourth instar larvae of Spodoptera littoralis (Boisd.) (Lepidoptera: Noctuidae). Mededelingen van de Faculteit Landbouwwetenschappen, Univ. Gent., 58 (2B):685-695.

8. Finney, D. J. 1971. Probit Analysis, a statistical treatment of the sigmoid response curve. $7^{\text {th }}$ ed., Cambridge Univ. Press, Cambridge, England.

9. Mead, Hala, M. I. 2006. Studies on biochemical and biological activities of some larvicidal agents on cotton leafworm, Spodoptera littoralis (Boisduval) (Lepidoptera: Noctuidae). Ph. D. Thesis, Faculty of Science, Suez Canal Univ., 220 pp.

10. Merdan, A. H. 1968. Studies on the effect of certain chemical entomopathogens on some cotton worms in Egypt. M. Sc. Thesis, Fac. Sci., Cairo Univ., Egypt.

11. Pineda, S., G. Smagghe, M. I. Schneider, Estal P. del, E. Vinuela, A. M. Martinez, and F. Budia. 2006. Toxicity and pharmacokinetics of spinosad and methoxyfenozide to Spodoptera littoralis (Lepidoptera: Noctuidae). Environ. Entomol., 35 (4): 856-864.

12. Raslan, S. A. 2003. Comparison of natural product Spinosad with some recommended insecticides for the control of the cotton leafworm at Sharkia Governorate, Egypt. Egypt. J. Appl. Sci., 18 (48): 665-675.

13. Snedecor, G. W. and G. W. Cochran. 1980. Statistical methods $2^{\text {nd }}$ ed. Iowa State Univ. Press Iowa, U S A.

14. Sun, Y. P. 1950. Toxicity index - An Improved method of comparing the relative toxicity of insecticides. J. Econ. Entomol., 43 (1): 45-53.

15. Willcocks, F. C. and S. Bahgat. 1937. The insects and related pests of Egypt. Royal Agricultural Society, Vol. I, Part II, 785 p. 


\title{
الأثر العام لبعض منظمات النمو الحشرية و المركبات الحيوية مقارنة بمركب كلوربيريفوس لاودة ورق القطن
}

\author{
عزت فرج الخياط1 ، وحيد محمود حسين دسوقى2² ،حمد محمد عزب1 ،

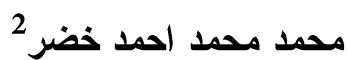

$$
\text { r ا ـ ـ معم وقاية النبات - كلبة الزراعة - جامعة بنها. }
$$

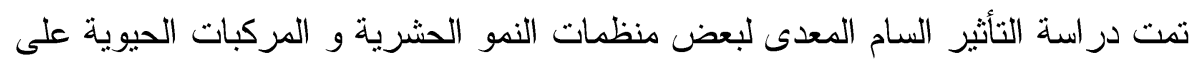

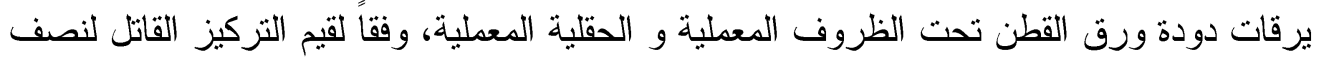
عدد الأفراد وكذلك لعدد 90٪ من الأفراد كان مركب كلوربيريفوس هو الأكثر سمية حيث سجل

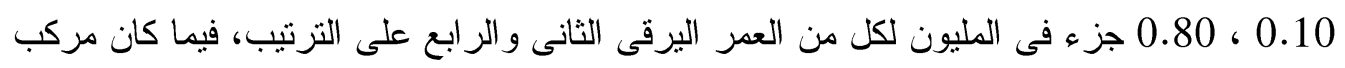
تييوفينوزيد هو الأقل فاعلية على كل من العمرين اليرقيين المختبرين حيث سجل 9.901 ، 9.901 ، 36.447 جزء فى المليون على التزتيب ضد العمر اليرقى الثانى و 15.636 ، 1000.757 جز الئل فى المليون ضد العمر اليرقى الرابع على التزتيب، فيما أعطت باقى المبيدات تأثيرات متوسطة على على الثى

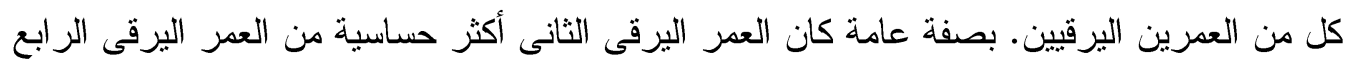
مع كل المبيدات المختبرة.

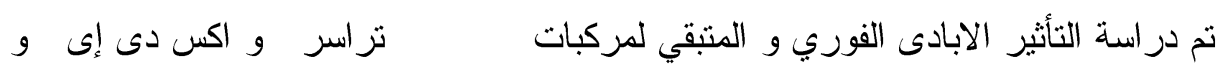
ميثوكسيفينوزيد و داييل تو اكس و كلوربيريفوس على سلالة حقلية ليرقات العمر الرابع لدودة ورق الادوق

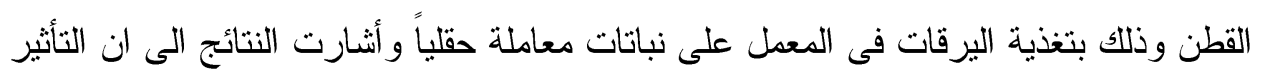

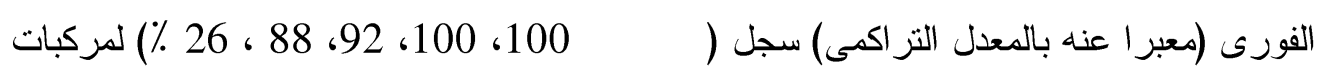
ميثوكسيفينوزيد و كلوربيريفوس و اكس دى إى و تز اسر و داييل تو اكس على الترتيب، فيما سجل

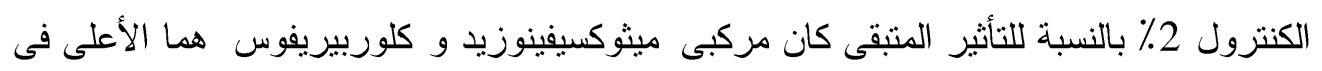
نسبة الإبادة على العكس من مركب داييل تو اكس الذي سجل اقل نسبة إبادة (18.40 ٪). 